\title{
Trends of Constitutional Amendments in Central Europe after 2008
}

\author{
IVÁN HALÁSZ*
}

\begin{abstract}
The Visegrad Group, the Czech Republic, Hungary, Poland and Slovakia, which forms the core of Central and Eastern Europe once more became constitutional and democratic states as a result of the changes of 1989. The global economic and financial crisis that began in 2008 has naturally shaken up the Central European region, but the intensity of its impact varied from country to country. The period between 2008 and 2010 hit Hungary the hardest, which led to the landslide political transformation of 2010. However, the economic and financial crisis that began in 2008 did not in itself lead to a new wave of constitutional legislation in Central Europe. The creation of a new constitutional identity in Hungary with the adoption of the Fundamental Law of 2011 has more to do with the local, specific political, social and perhaps partially legal historical conditions. At this time, the other Visegrad countries can be characterised by maintenance of the constitutional status quo or only partial amendments. It is true that in these countries the turbulence caused by the crisis has not yet lead to a single party or coalition achieving the qualified majority required for constitutional reform. The situation in Poland after 2015 is still open but the new government does not have the necessary majority for the adoption of new constitution. The constitutional amendments adopted after 2008 were only a partial reaction to the great economic and financial crisis. Rather, many amendments were reflections on structural problems that had existed previously or problems arising in the course of day-to-day politics that had not been fully considered previously or they introduced long-debated and still timely changes.

Among new trends, the protective measures applicable to natural assets and waters were introduced in the interest of future generations. These were inserted in a very forceful manner into the Hungarian and Slovakian constitutional systems during the post-crisis period. The reinforcement of such an ecological identity could be interpreted as a positive development. However, the public law documents of the region are also characterised by a certain conservative 'revolutionary' mood including the definition of marriage as a relationship between a man and a woman; some family law measures aimed at improving demographic conditions and the passages of the Hungarian Fundamental Law concerning a society based on work. The function of constitutional courts is also beginning to be re-evaluated in the region, mainly in Hungary and Poland.
\end{abstract}

Keywords: amendment, Central Europe, constitution, constitutional court, crisis, parliament

\section{INTRODUCTION - THE LEGAL BASIS OF CONSTITUTIONAL AMENDMENTS IN CENTRAL EUROPE}

The Visegrad Group, the Czech Republic, Hungary, Poland and Slovakia, which forms the core of Central and Eastern Europe once more became constitutional and democratic states as a result of the changes of 1989 Their new constitutions, adopted between 1989 and 1997, essentially reflected the spirit and the values of the democratic transition. During that period, with one or two exceptions, the definitive Western models of constitutional democracy rather than previous national legal traditions influenced the new constitutions.

* PhD, Professor at the Faculty of Political Science and Public Administration, National University of Public Service - Institute for Legal Studies, Centre for Social Sciences of the Hungarian Academy of Sciences. Halasz.Ivan@tk.mta.hu This paper was prepared with the support of the Incubator Project 'The Development of the Electoral Systems and Function of Party Systems in Central and Eastern Europe' of the Centre for Social Sciences of the Hungarian Academy of Sciences. 
The wave of new democratic constitutions after 1989 was not really creative and innovative but instead followed and copied others. ${ }^{1}$

The new democratic constitutions produced in the 1990s turned out to be highly flexible documents. This was partly as the consequence of previous traditions of public law (largely in Czechoslovakia and Hungary) and perhaps a reaction to the protracted periods of adopting new constitutions that generally characterises changes of the political system. The Hungarian wording of the constitution established in 1989/1990; the Slovakian constitution of 1992 and the Czech constitution of 1993 could all be easily amended with a qualified majority. The only difference was that in Hungary, a two-thirds majority of all the members of parliament was required, while in Slovakia ${ }^{2}$ and the Czech Republic, a three-fifths majority in both houses of parliament was the norm. ${ }^{3}$

In Poland, the situation is more complicated as an amendment of the constitution requires a two-thirds majority of members of parliament and an absolute majority of senators and quorum in both houses only requires at least half the members to be present. An added complication is that any constitutional amendment that involves the provisions of Chapters One, Two and Twelve of the constitution ${ }^{4}$ requires a confirmatory referendum. The constitutional amendment is considered adopted if the majority of the voters submitting valid votes of support. ${ }^{5}$

One consequence of this flexibility is that members of parliament in these countries often resort to amending the constitution. The Slovak Constitution, adopted in 1992 and still in effect, has been amended a total of 13 times. ${ }^{6}$ The situation was similar with the

1 The resistance to experimentation was noted in a few articles by Adam Michnik, and Jürgen Habermas also noticed the trend at the time.

2 See Art. 84 (4) of Slovak Constitution:

For the purpose of adopting or amending the Constitution, a constitutional law, in approving an international treaty according to Art. 7, para. 2, for the adoption of a resolution on plebiscite on the recall of the President of the Slovak Republic, for bringing a prosecution of the President and for the declaration of war onanother state, the consent of a three-fifths majority of all Members of Parliament shall be required.

${ }^{3}$ It should be noted that the Czech and the Slovakian constitutional orders, like the Austrian system, are not established in a single document (charter) but in the constitution in the narrow sense itself and the Czechoslovakian Charter of Fundamental Rights and Freedoms enacted in 1991. In both countries, the constitutional laws adopted with the majority required for constitutional acts. Article 9, paragraph (1) of the Czech Constitution states that the Constitution may only be supplemented or amended by constitutional acts. A constitutional act requires a three-fifths majority of all the members of parliament and of all the senators present, similar to the adoption of a new constitution.

${ }^{4}$ Chapter One is entitled The Republic and deals with the fundamental characteristics, values, objectives and symbols of the Polish state. The second, lengthy chapter is about human and citizen's rights, freedoms and obligations. Chapter 12 is about the rules governing amendment of the constitution.

${ }^{5}$ For those rules, see Chapter 12 of the effective Polish Constitution (the chapter consists of a single long article, Article 235).

${ }^{6}$ Amendments took place in the following years: 1998, 1999, 2001, 2004, 2005, 2010, 2011, 2015. In 2006 and 2014, the Slovakian parliament amended the wording of the constitution twice in a single year. Exceptional among those amendments is the great amendment of 2001, which affected a great many provisions of the constitution. That large set of amendments reacted to the period prior to 1998 when the Slovakian government had been headed by Vladimír Mečiar. There were very many abuses and the political system began to exhibit a number of authoritarian trends. The alternative to the great amendment would have been the adoption of a new constitution but that option was finally 
Hungarian constitutional text from 1989 (officially the Act No. XX. from 1949 totally amended in 1989) as well, with 38 amendments in total. The Czech Parliament has exercised greater constraint with only four real amendments of the constitution from 1993 to 2016 . $^{7}$ It is however true, that the Czech Parliament 'outsourced' a number of important issues into constitutional laws. The Polish Parliament has been the most reserved with only two amendments since the adoption of the effective constitution.

The global economic and financial crisis that began in 2008 has naturally shaken up the Central European region, but the intensity of its impact varied from country to country. ${ }^{8}$ The period between 2008 and 2010 hit Hungary the hardest which led to the landslide political transformation of 2010. The Polish economy suffered perhaps the least from the crisis. The Czechs were assisted by their good economic foundations, some of which date back to the interwar period. In the period after 2008, the greatest changes of public law took place in Hungary. Signs of a severe political crisis were already in evidence in 2006, primarily in the increasing violence of anti-government demonstrations. ${ }^{9}$ At the turn of $2007 / 2008$, the economic crisis knocked on the country's door. The government at the time only managed to avert a financial collapse to some extent, by implementing severe austerity measures. The consequences of those measures were felt at the 2010 parliamentary elections when the opposition right-wing parties achieved the qualified majority required for passing a new constitution. In 2011, the new majority used the opportunity and adopted Hungary's new Fundamental Law despite during the 2010 election campaign, when they had been still in opposition, they had not promised to introduce a new constitution.

There have several partial amendments of the Central European constitutions after 2008 as well as the new Fundamental Law in Hungary, which is more or less the direct consequence of the big (political and economical) crisis from the second part of the first decade of the $20^{\text {th }}$ century. Only one part of these amendments is a consequence of the economic crisis from 2008. Many amendments resulted from the specific constitutional and political situation in these countries. The main goal of this article is the identification of the post-crisis elements inside the current process of constitutional changes in the Visegrad region and the differentiation of the old (traditional) and new (post-crisis) reasons for these constitutional amendments.

The process of constitution-making has always two dimensions. The first and main dimension is the process of adoption of the new constitution. The second dimension is represented by the later amendments of the valid constitution(s). This paper is primarly focusing on the analysis of the reasons for the constitutional changes in the Visegrad countries after 2008, and paralelly on the analysis of the amended constitutional texts as well. The wider political and ideogical context of these changes is here irrelevant. The Fundamental Law of Hungary and its amendments

The new Fundamental Law of Hungary, adopted in April 2011, was an interesting turning point in the development of the country's public law. From the structural perspective,

rejected both by the post-communist left-wing democrats who had worked on the 1992 constitution and the conservative Christian Democrats, with their emphasis on continuity. Those two parties constituted almost half the governing coalition.

7 This was done in 1997, 2001, 2002 and 2012.

8 With the constitutional aspects of political, social and economical crisis in Central Europe is dealing in complex form Blokker (2013).

9 One such event involved radical right-wing demonstrators breaking into the building of the public television station in early autumn, 2006. 
the document did not introduce any spectacular changes, perhaps with the exception of reducing the scope of authority of the constitutional court, yet it still changed the identity of the system of public law. The title itself indicates this change as the new document is not called a constitution but a Fundamental Law. The word 'constitution' does occur in the text but only in reference to the historical constitution, whose values the authors wish to return to. The authors do not specify clearly whether the historical constitution ${ }^{10}$ has really been placed back in effect. However, it seems that the history constitution has not, partly as a consequence of the fact that Fundamental Law itself has been created and one of its important Articles (Article $\mathrm{R}$ of the Foundation) declares itself to be the foundation of the legal system of Hungary. It is also true that according to the same article, the provisions of the Fundamental Law shall be interpreted in accordance with their purposes, the National Avowal i.e., the preamble ${ }^{11}$ contained in it and the achievements of the historical constitution suggesting that the historical constitution has some sort of longer term role.

The new Hungarian constitution of 2011 did not simply bring a revival of old-fashioned legal norms and terms ${ }^{12}$ but it also contains a number of new provisions and measures. A part of those could be considered to be the straightforward consequences of the previously mentioned crises. The category certainly includes green, i.e. ecological provisions of the Fundamental Law as well as the provisions that react to new technologies. They include, for instance, the prohibition of practices aimed at eugenics; the use of the human body or its parts for financial gain and human cloning. The transport of pollutant waste to the territory of the country for the purpose of disposal has also been prohibited. The Fundamental Law specifically mentions future generations and Article $\mathrm{P}$ of the Foundation states that natural resources, in particular arable land, forests and the reserves of water, biodiversity and cultural assets form the common heritage of the nation, which the State and everyone are obliged to protect, maintain and preserve for future generations. The provisions of the Fundamental Law concerning the family and work-based society are also new. A certain shift in values is also shown by the Fundamental Law devotes more attention to citizen's obligations alongside rights. Indirectly, that is also expressed in the title of the major section about those issues: 'Freedom and Responsibility'. ${ }^{13}$ The Fundamental Law, as a result of that attitude, also contains a statement to the effect that Hungary shall encourage the commitment to have children; defines marriage as the union of a man and a woman and the authors also stated that adult children are also obliged to take care of their parents if they are in need just like parents are obliged to take care of their minors. The text of the constitution, presumably as a reaction to the economic and financial crisis, also contains provisions concerning budgetary discipline and the enforcement of the principles of a balanced, transparent and sustainable budget management in the long term - things for which primarily Parliament and the government are responsible. In relation to that, as a new

${ }^{10}$ Actually, Hungarian historians of law use the term 'historical constitution' to refer to the corpus of statutes prior to 1945, sometimes also called the 'thousand-year-old constitution', i.e. the legal norms that were built on each other and which regulated the most important issues of the Hungarian state from the early Middle Ages until World War II. No specific legal norm has ever actually stipulated exactly which foundational laws belong in that corpus and which do not. See Fejes (2015) 25-44.

11 Fekete (2015) 11-24.

12 For instance the 'Holy Crown', the 'historical constitution' or the 'Curia' (Supreme Court). Regarding the new terminology of Hungarian constitutional law see Schweitzer (2012) 258-65.

13 Regarding the problem of the protection of human rights see Téglási (2014) 317-39. 
institution, the wording of the Fundamental Law mentions the Budget Council, ${ }^{14}$ consisting of the Governor of the National Bank, the President of the State Audit Office and the President of the Budget Council, appointed by the President of the Republic for a term of six years. Prior consent of the Budget Council is required for Parliament to approve the annual central budget.

The Fundamental Law did not make any significant changes to the organisation of the state, which retains a mixture of elements from the presidential and the parliamentary systems. ${ }^{15}$ The lack of changes is probably due to the fact that if the winner of the elections has a clearcut majority in parliament and a sufficiently disciplined faction, the resulting Government has a very wide scope of authority under that system. ${ }^{16}$ A suitable parliamentary majority is assured in Hungary by a relatively complex, mixed electoral system. The winners of the 2010 elections introduced various partial reforms during the period until 2014 to tilt that system further to their advantage. ${ }^{17}$ The constitional court, which had a wide scope of authority up, was the only real check and balance upto 2010 in a Hungarian public law system based on an almost omnipotent parliament, a strong prime minister ${ }^{18}$ and a weak, indirectly elected head of state, Therefore it is not surprising that the reduction of the authority of that body and the changing of its membership began before the adoption of the new Fundamental Law, a mere few months after the elections. ${ }^{19}$

The essence of the changes is that under the new system, the candidates for membership of the Constitutional Court are also appointed by the parliamentary majority while the President of the Constitutional Court is no longer elected by the members from among themselves but appointed by parliament. The mandate of the judges has also been increased from 9 to 12 years, but they can not be re-elected. It is perhaps an even more important change that the Constitutional Court now has a much more limited scope of authority on budgetary, economic and financial issues.

The authors of the 2011 Hungarian constitution created the new Fundamental Law in the hope of a new beginning. In contrast with the ideological minimalism of the previous constitution, the new one is quite verbose and attempts a detailed explication of the values and preferences of the majority that wrote it. The new Fundamental Law, like most acts of this nature, was also written with the expectation that it will be in effect for a long time although the authors did not make it more difficult to amend the constitution. It is probably a consequence of that fact that, paradoxically, the Fundamental Law, adopted in 2011 which is considered 'solid as a rock' has been amended six times in 2012-2013 by the same parliamentary majority. Organisationally, the six amendments were primarily concerned with the reform of electoral law and the judicial system, essentially centralisation and the replacement of personnel. In addition, the fourth amendment of the Fundamental Law, considered the most problematic, attempted to stop the Constitutional Court from using the principles laid out in its resolutions and its previous jurisprudential practice as a foundation

14 Szalai (2014) 279-80.

15 See Cserny (2015) 131-47 and Mandák (2015) 148-68.

16 See Körösényi (2015) 417-18.

17 For instance by introducing a first-past-the-post, single-round electoral system and granting the vote to Hungarian citizens permanently resident outside the country, most of who tend to favour the right wing, etc. 292-95.

18 Regarding the position of Hungarian prime-minister before and after 2010 see Cserny (2014)

19 About the changes of the position of Constitutional Court see Szalai (2014) 275-79. 
after 2011 and to keep referring to decisions made prior to the adoption of the Fundamental Law. ${ }^{20}$ That amendment also included a number of ideological pronouncements, primarily directed against the communist past and its heirs.

It should be noted here that the 2011 process of creating the new Hungarian constitution was intensively scrutinized by Pan-European bodies and the international professional and political community. ${ }^{21}$ International interest intensified further after the adoption of the fourth constitutional amendment, particularly due to its strongly ideological character and some truly questionable measures curtailing the powers of the judiciary. The latter mainly concerned the authority to move cases between courts, an entitlement that was granted to the President of the National Office for the Judiciary, a body that controls and manages the judiciary system. This turned out to be one of the few cases in which the Hungarian legislator yielded to the pressure of international and European level criticism. This primarily took the form of the most problematic elements of the fourth amendment being partially taken back in the fifth one. The latest amendment of the Fundamental Act took place in the spring of 2016. It was motivated by the present migration crisis. In relation to that, the part of the Fundamental Act regulating extraordinary circumstances were amended with a new type of circumstance, the risk of terrorist acts. Such an emergency may be declared by parliament with a two-thirds majority at the government's initiative in case of a terrorist attack or the immediate danger of a terrorist attack. The amendment was supported not only by government MPs but also by the right-wing opposition. ${ }^{22}$

\section{SLOVAKIA}

No radical constitutional changes have taken place in the other Visegrad countries after 2008. Around the turn of the millennium, Slovakia was actually quite close to adopting a new constitution, but that, naturally, had nothing to do with the 2008 global economic and financial crisis but rather with the internal politics of Slovakia of the time. The notion of a new constitution was largely a reaction to the country's political landscape prior to 1998, when Vladimír Mečiar had been the Slovakian prime minister a great many abuses had occurred - there was a fear in many people of a return to an authoritarian system. All of that had occurred during the period already regulated by the constitution adopted in 1992, so many opposition figures blamed that document for the problems of the 1990s and wanted to replace it with a new constitution. In the end, this did not happen and there was only a major amendment of the constitution, which was passed in 2001. This impacted many parts of the original document and was a certain fine tuning but, it did not alter the essential identity and the structure of the constitution of 1992.

During the period after 2008, the notion of a new constitution has not occurred to any of the definitive political powers in Slovakia. The concept was raised by the civil activists who demonstrated very intensively in the streets against the corruption of the political elites

${ }^{20}$ Regarding the changes connecting to the constitutional court see Gárdos-Orosz (2015) 114 28 and Szente (2015) 185-210 and Erdős (2014) 397-417.

${ }^{21}$ About the Hungarian Fundamental Law in the European constitutional context see Chronowski (2014) 109-30.

22 The 199-member strong Parliament voted as follows: 153 yes, 13 no, 1 abstention. $<$ http:// mno.hu/belfold/terrorveszely-megvan-az-alaptorveny-hatodik-modositasa-1345940> accessed 09 August 2016. 
in 2011 and 2012. It was a period of the so-called Gorilla ${ }^{23}$ corruption scandals. Roused by the grass-roots movement in Iceland to write a new constitution, which was also unsuccessful but seemed promising at the time, the civil activists ${ }^{24}$ initiated a socialprofessional debate about the new constitution but the idea came to nothing when none of the parliamentary parties in supported them and their own power was insufficient

During the period after the beginning of the economic and financial crisis, Slovakia was the country most often amended its effective constitution, currently six occasions. The majority of those amendments, however, were not so much attributable to the crisis but to Slovakian internal politics and the functioning of the state. One exception is Constitutional Act no. 100 of 2010, initiated by the first Fico government, ${ }^{25}$ which amended Article 20 of the Slovakian Constitution on the protection of property in two places. According to the new text "Other interference with property rights may be permitted only in the case of property acquired in an illegal manner or from illegal earnings, and if it is necessary in a democratic society in the interests of national security, preservation of public order, good morals or the rights and freedoms of others. Conditions shall be stipulated by law." This amendment has reflected the problem of big fortunes gained in immoral and illegal manner after the transition in 1989 and in this form, it is a consequence of the intensive social dissatisfaction.

The second large amendment of the postcrisis period has reflected the Slovak political crisis from autumn 2011. The big question of that time was the European financial support for Greece. The conservative-liberal Slovak government supported this idea but one member of coalition did not agree. Prime minister Iveta Radičová initiated a vote of confidence but the Slovak liberals ${ }^{26}$ did not support the government. This vote opened the road for return of Robert Fico lead SMER-Social Democracy party, which governed in Slovakia between 2006 and 2010 and against between 2012 and 2016.

The Constitutional Act no. 356. from 2011 has regulated the constitutional situation between the unsuccesfull voting of confidence and the creation of the new government after election. The main innitiative impulse arrived from Robert Fico and president Ivan Gašparovič, ${ }^{27}$ his political ally. The amendment from 2011 strengthened the constitutional position of President and has weakened the position of Slovak government in the period after the voting of confidence. According to the reform in the event that the National Council has passed a vote of no-confidence or overruled a motion for a vote of confidence, the President shall dismiss the Government. In the case where the President has accepted resignation of the Government, they should delegate all powers continuously to be exercised by the former Government until a new Government has been appointed. If the President of the Slovak Republic recalls the government in accordance with constitution, then by a decision promulgated in the Collection of Laws, the President shall charge that government

${ }^{23}$ Gorilla was the name of the special documents of police about the high level corruption.

24 E.g. Juraj Marušiak, Eduard Chmelár etc.

25 Robert Fico was the prime minister of Slovakia first between 2006 and 2010. He became the prime minister again in 2012 after the pre-term fall of the previous government and was able to serve out his second term (2012-2016) as well.

26 The official name of party is Freedom and Solidarity (Sloboda a Solidarita, SaS).

27 Ivan Gašparovič was president of Slovak Republic between 2004 and 2014. He was formarly a speaker of Slovak parliament in the period of Vladimír Mečiar government. Originally, he was lawyer and professor of criminal law of Comenius University in Bratislava. The current Slovak president is Andrej Kiska. 
with further performing its competences until a new government is appointed, but solely those competences set out in Article 119.a.b.e.f.m.n.o.p.r. ${ }^{28}$ In addition, however, the performance of government competences set out in Article 119.m) and r) points requires the prior approval of the President in each individual case. Practically, the President Ivan Gašparovič has achieved the rights to veto in every important personal competence. The 'limited' government before the new elections lost the right to presentation of new governmental program and right to ask form parliament the new vote of confidence. In this controversial period, the government did not have the possibility to discuss the important political question, the government lost the right to turn to the constitutional court and the right to give general pardon.

The next amendment is even more technical. The Constitutional Act n. 232 from 2012 has dealt with the immunity of MPs and with the legal status of MPs. This amendment was born during the second Fico government (2012-2016). According to the new text of Article 78., no Member of Parliament shall be prosecuted for their voting in the National Council of the Slovak Republic or in its committees, even after expiration of their mandate. No Member of Parliament shall be prosecuted for statements presented in duration of the post in the National Council of the Slovak Republic or in its body, even after expiration of their mandate. The Member of Parliament is subject to disciplinary powers of the National Council of the Slovak Republic. No Member of Parliament shall be taken into custody without the consent of the National Council of the Slovak Republic. If a Member of Parliament is caught and arrested while committing a criminal offence, the competent body shall be obliged to notify immediately the President of the National Council and the Chairman of the Mandate and Immunity Committee of the National Council of the Slovak Republic. If the Mandate and Immunity Committee of the National Council of the Slovak Republic does not subsequently approve the arrest, the Member of Parliament must be released immediately. In duration of the arrest, the mandate of a Member of Parliament is not terminated but should not be exercised.

The second largest amendment of the Slovak constitution was made in 2014. (The first large constitutional reform was adopted in 2001). The Constitutional Act no. 161. from 2014 was adopted by the coalition of governing SMER-SD and the christian democratic

28 According to the Articul 119.a.b.e.f.m.n.o.p.r.

[T] he government shall decide as a body a) on draft laws, b) on government regulations [...] e) on draft state budget and final state budgetary account, f) on international treaties entered into by the Slovak Republic whose negotiation the President of the Slovak Republic has delegated to the Government, $[. ..] \mathrm{m}$ ) on the appointment and recall of other state officials in cases laid down by a law and three members of the Judicial Council of the Slovak Republic, n) on a proposal for declaring a state of war, on proposal for ordering amobilization of the military forces, on proposal for declaring an exceptional state and on a proposal for their termination, on declaring and on termination of a state of emergency, o) on despatching the military forces outside of the territory of the Slovak Republic for the purpose of humanitarian aid, military exercises or peace observing missions, on the consent with the presence of foreign military forces on the territory of the Slovak Republic for the purpose of humanitarian aid, military exercises or peace observer missions, on consent with the passing of the territory of the Slovak Republic by foreign military forces, $p$ ) on despatching the military forces outside of the territory of the Slovak Republic if it regards performance of obligations resulting from international treaties on joint defence against attack for a maximum period of 60 days; the Government shall announce this decision without undue delay to the National Council of the Slovak Republic, [...] r) on other issues if the law provides so. 
part of opposition. The amendment has introduced a new definition of marriage as the relationship between a man and a woman. This conservative declaration was the old political aim of christian democrats, regardless of any crisis. The second part of amendment dealt with the reform inside the Slovak justice. The problem of the self government of justice (judges) is an old and sensitive question of the Slovak political life, because the post transitional Slovak justice has had many problems and turbulences. This problem is independent from the crisis in 2008 and rather is connected with the EU membership of Slovakia.

Slovakia is currently the part of the wider European legal space and this has important consequencies for the activities of the Slovak supreme and constitutional courts. Here exists the possibility for conflicts between the Slovak courts and European courts in Strasbourg and Luxemburg. The constitutional amendment has reflected this situation. The constitutional court violated finality of its judgments when it introduced new provision stating that, against decisions of the constitutional court, it is now possible to submit an extraordinary remedy. The new provision refers to reopening of a trial after a decision of an international organ of an international treaty by which Slovakia is bound gave rise to the obligation to revise a decision of the constitutional court (see Art. 133 of the constitution). The amendment dealt with the immunity of judges of constitutional court too. Every criminal procedure (trial) against the constitutional judges need currently the consent of constitutional court. However, judges (not only constitutional judges) cannot be taken into pre-trial detention without the consent of the constitutional court. The constitutional court became the main forum for the discipline cases of the president of supreme court, her/his deputy and attorney general.

The former single function of the president of the supreme court and the president of Judicial Council were also separated. The president of the Judicial Council is now one of the highest state officials in terms of material benefits unlike the rest of Judicial Council members who hold only honorary offices in the council. The powers of the Judicial Council were extended for the purpose of its increased role in the administration of justice. The Judicial Council has acquired authority to issue an Ethical Code for the judiciary with cooperation of the justice councils. The amendment from 2014 introduced a new condition for future as well as incumbent judges. All judges must now fulfil "preconditions of judicial abilities." The preconditions in general should help to assess judges and candidates from ethical, personal and social points of view. Preconditions are assessed by the Judicial Council during the process of appointment on the basis of information provided by national security secret service. A candidate will not become a judge if they do not fulfil the criteria. This condition for holding a function has a retroactive effect. ${ }^{29}$ Judges and candidates for judges can lodge an appeal against negative decisions of the Judicial Council on the constitutional court whose decision is final. This retroactive effect was the reason for the case before the Slovak constitutional court. ${ }^{30}$ The question of the constitutionality of constitutional amendments and their judicial review is very sensitive question in Slovakia.

2014 was very full of constitutional amendments. The first amendment appeared in spring, the second amendment of Slovak constitution coming in the autumn and dealt with the ecological and environmental questions (Constitutional Act no. 306. from 2014). This amendment has supplemented the Constitution in two important ways. Firstly, it added a

29 Here exists the difference between the judges appointed before and after 1st september 2014.

30 See Pl ÚS 2014/21. 
provision of declaratory nature to Art. 4 stating that Slovak Republic protects and enriches natural heritage and the Slovak Republic uses its heritage effectively and gently in benefit of Slovak citizens and future generations. Secondly, this amendment created rather limited regime of doing business with water from Slovakia. It is currently forbidden, according to the new constitution text, to transport water abroad, from water resources in Slovakia by means of transportation or pipelines. This restriction however does not include water for personal consumption, drinking water and natural mineral water packed to consumers' packages within Slovakia and to provide water for humanitarian aid and in a state of emergency.

The last, for now, amendment of Slovak constitution (Constitutional Act. no. 427. from 2015) was born in 2015 in the coproduction of the governing SMER-SD and oppositional Slovak-Hungarian mixed party Híd-Most (Bridge). ${ }^{31}$ This amendment has supplemented Article 17 paragraph 3 that protects the right to personal liberty. In respect of terrorist acts, the amendment has extended the time-limit for a person to be brought before a judge from 48 hours to 96 hours or be released. This change has instigated by the terrorist attacks in Paris in November 2015.

\section{THE CZECH REPUBLIC}

The Czech Parliament has directly amended the text of constitution only eight times. ${ }^{32}$ between $1992^{33}$ and 2016. The Czech constitutional system is polylegal ${ }^{34}$ and the constitution is only one part of this system. The Charter of Fundamental Rights and Basic Freedoms is very important and was adopted by Czechoslovak Federal Assembly in 1991. The constitutional acts, adopted by two chambers of Parliament represent the third type of source of constitutional law in the Czech Republic. The current paper is mainly concerned about the direct amendments of constitution and on the important constitutional acts.

After 2008, the Czech legislature exercised its right to amend the constitution somewhat less often than the Slovakian one. The first constitutional amendment of the period was a reaction to internal political problems and attempted to resolve a previously unregulated hiatus. The 2009 constitutional amendment established the right of the head of state to dissolve the House of Representatives if this is recommended by the House, with a three-fifth majority vote of MPs in favour of such a step.

Constitutional Act no. 71 of 2012, on the other hand, represented the so far greatest structural change of the Czech state, as it introduced direct election of the head of state by popular vote. The change, along with that of 2009, was not related to the economic and financial crisis, as the option had been discussed for a long time by Czech politicians and jurists. It is more of a general trend that has characterised the entire Central and Eastern European region in the wide sense in recent years and now only has a few exceptions e.g., Hungary. The abovementioned constitutional amendment did not just regulate the election of the president of the republic but also the rules of their indictment. In other particulars, it

31 The general election in spring 2016 resulted in these parties coming together with the Slovak National Party to create the new governmental coalition in Slovakia.

32 Jirásková (2015) 56.

33 The first constitution of the independent Czech Republic was adopted by the Czech National Council in december 1992. The constitution is valid from 1st january 1993.

34 Regarding the Czech polylegalism see Kudrna (2011) 19-22. 
left the scope of authority of the president untouched. Nevertheless, the president's position has been growing observably stronger in the Czech Republic. ${ }^{35}$

The latest Czech constitutional amendment so far was passed in 2013. Constitutional Act no. 98 of 2013 reduced the legislative immunity of members of parliament, senators and constitutional court judges. Before the amendment was adopted, if the House of Representatives or the Senate refused to grant the approval required for the commencement of criminal proceedings against a representative or a senator, criminal indictment in the case could never take place. After the amendment, the immunity only lasts as long as the person's mandate, and the procedure can be launched once the mandate is over, provided that the statute of limitations has not expired,. The change is largely related to long-standing disputes and the general trend of reducing the immunities that were regulated rather generously in the early 1990 s.

\section{POLAND}

The 1997 Polish constitution was adopted after long and thorough negotiations and essentially as a compromise between the then still strong post-Communist democratic left, the popular party representing rural areas and the liberals who were the offspring of the Solidarity movement. ${ }^{36}$ The right-wing parties that had also grown out of Solidarity were the most vocal opponents of its adoption, particularly because they had very limited opportunities to influence its content as they were not parties not in parliament at the time. The constitution has actually worked quite well as a balanced document. and over the last two decades, it has stabilised the Polish system of public law and the country's politics. This is evidenced among other things by the fact that the document has not been amended much, and none of the changes were related to the great economic and financial crisis, not even the amendment passed in 2009. The changes were largely reflections on the country's EU membership and its internal politics.

After the turn of the millennium, the right-wing conservative national party Law and Justice (PiS), in power between 2005 and 2007, was the most critical of the new constitutional system. In fact they were not merely critical; they elaborated a completely new draft constitution. The more radical factions of the Polish right wished to use it to close the troubled post-communist period and create the foundations for the so-called 'fourth Polish Republic'. ${ }^{37}$ However, the plan failed and the PiS party remained in opposition for long years. In 2010, the PiS, in opposition, submitted a great bill of constitutional amendments that they claimed was an attempt to achieve the birth of the 'fourth republic' in a gradual, evolutionary manner. According to that bill, the public law position of the Polish head of state would have grown substantially stronger within the existing parliamentary cabinet system. The president of the republic would no longer have been a part of the executive branch, but would have stood above all the branches of government

35 About the relationship between the president and government see Tomoszek (2015) 152-59.

36 See Chruściak - Osiatyński (2001).

37 That's because Polish public law literature and journalism distinguish three Polish republics: the Polish-Lithuanian 'feudal republic' that ceased to exist at the end of the $18^{\text {th }}$ century, the 'second republic' that existed between the two world wars and the 'third republic after 1989. The people's republic under Communism is not numbered, as it is not considered a real republic. 
and would also have been the president of the reformed National Judicial Council, whilst in some cases they would have had the right to refuse to appoint the prime minister and other ministers. They would have had the right to refuse to sign individual acts of parliament and to initiate referenda about them, and such referenda would have had an impact on the length of the mandate of the legislature. ${ }^{38}$ At that time, that draft came to nothing but it is a largely accurate depiction of the ideas of the political force that regained power in 2015.

The critical attitude to the Polish constitution from 1997 and to the functioning of post-communist Polish state was typical in the last decade. Jaroslaw Kaczyński as a leader of PiS summarised this question in 2010 in a lecture at the Jagellonian University in Cracow:

There are no conditions in Poland for a state of law and a law-governed state to exist in Poland. Let us now reflect on the consequences brought about by the application of rules derived from the concept of 'state of law' in our country. In Poland, during the last twenty years, some elements of a state of law have been built. These elements, however, lead to some rather specific consequences, which can be connected to the consequences of the absence of law. By the 1980s the process of 'juridification' of the communist system had already begun. Many things were regulated which had not been regulated before. Certain institutions were established, including the Constitutional Tribunal, the ombudsman, the administration courts. This process was very farreaching. A situation came about, in which no decision could be taken without a legal basis. This limited the rational freedom of decision-making by the persons who hold various public offices. ${ }^{39}$

Marta Bucholc, the Polish-German researcher citating this speech, has commented on it

In this address Kaczyński does not negate the value of the state of law. Quite the contrary, he suggest that the rule of law cannot be introduced in Poland because the necessary conditions have not been fulfilled, which is why all the elements of rule of law that are already in place are dysfunctional: they could only function well in an appropriate context. One crucial element of this context is the freedom to act on the part of the authorities, which may do not be 'irrationally' limited by the law. A conclusion of this reasoning might well be that the law has its place as a regulatory framework of social action, but state power may not be subjected to the law: the authorities must have more freedom than the citizen. ${ }^{40}$

38 PiS proponuje nową konstytucję - władza dla prezydenta, Nowy Dziennik, 15.0.2010<http:// www.dziennik.com/wiadomosci/artykul/pis-proponuje-nowa-konstytucje-wladza-dla-prezydenta> accessed 31 July 2017.

39 Original source: Kaczyński, Jaroslaw: Czy Polska jest państwem prawa? Wyklad na Uniwersytecie Jagellońskim. Pressje, 24. pp. 222-29. <http://pressje.pl/media/pressje_shop/atricle/ article issue_7.pdf $>$ Translation of the text in: Bucholc (2016) 9 .

${ }^{40}$ Bucholc (2016) 9. 
This theoretical and ideological context is very important for the understanding of the Polish political processes in the last two years. From 2015 the PiS has two most important positions in the Polish constitutional system - the majority in the two chambers of Parliament and the position of president. It appears that the Polish parliamentary majority elected in the autumn of 2015, PiS together with non-governmental, but cooperative "Kukiz'15" Movement, ${ }^{41}$ lacking the qualified majority required for a new constitution, ${ }^{42}$ now prefers to change the constitutional system in an evolutionary, i.e. gradual manner. Their plans are less grandiose than in 2005-2007, but may turn out to be more effective. The main trend of the currently known schemes for changes concern amendment of the competency of the constitutional court, changing the body's composition and imposing obstacles to its operation. The constitutional court meant the last important constitutional organ, which was independent from the influence of the new majority. The political and legal scandals around the body began in the autumn of 2015 and gained further momentum after the general elections.

In December 2015, the new majority in the Polish legislature (with PiS and "Kukiz'15" votes $)^{43}$ actually adopted an amendment to the Constitutional Court Act, ${ }^{44}$ but the Polish constitutional court declared it unconstitutional resulting in a stalemate in the Polish system of public law. The ad hoc (but not formal coalitional) Block of PiS and "Kukiz'15" have initiated the amendment of constitution. The essence of the project of changes from December was, or rather would have been, to increase the number of constitutional judges to 18 . Their mandate would have remained 9 years, but without the possibility of reelection. They would have to be elected by a two-thirds majority. The president and vicepresident of the body would be appointed by the head of state, choosing from among three persons nominated by the college of constitutional judges. The constitutional nature of the Constitutional Court Act (and international treaties) would no longer be reviewed by the Constitutional Court but by the Supreme Court. In addition, 60 days after the date of effect of the constitutional amendment, the mandate of all existing constitutional judges would be terminated and a new body would have to be elected. That last one was probably the most significant goal of the entire initiative.

41 The leader of this new protest and populist movement (Kukiz) is also critical to the constitution from 1997. According to his opinion this constitution is archaical and it is a result of the 'post-bolshevik compromise' from 1989. This document was good for the period of postcommunist transition without violence, but it is not good for the new and modern Poland. Kukiz: 'Im gorzej w kraju, tym lepiej dla mojej koncepcji.' See: <http://www.newsweek.pl/polska/michnikostrzega-przed-pis-w-gazecie-wyborczej, artykuly,375428,1.html> accessed 31 July 2017.

42 The relatively similar PiS and Kukiz'15 could only amend the constitution if they were supported by the opposition, or if the latter boycotted the vote. At present, those two parties have 276 mandates in the Sejm, while, provided all representatives are present, a constitutional amendment would require 307 votes.

43 These political parties do not create the official coalition. Only PiS has formed the government. These parties are only occasional partners in several special questions (e.g. the issue of Constitutional Court). The populist movement 'Kukiz ' 15 ' is following its own policy.

44 See Wilgocki and Kośmiński (2015). 
In July 2016, the Polish legislature once more adopted the new Constitutional Court Act that accords with the will of the parliamentary majority, ${ }^{45}$ but the new law has been still a subject of debate between the European Commission and Poland, and the opposition are also attacking the document. The Venice Comission of Council of Europe has also criticised this norm. ${ }^{46}$ For this adoption the Parliament did not need the constitutional majority, ergo this Act does not mean the amendment of constitution. Finally, the Polish legislature in early Winter 2016 adopted the new Act, which would introduce the former amendments from Summer 2016. This Act intensively regulates the status of constitutional judges and the procedural questions of the constitutional court. However, the acts connecting to the constitutional court do not mean the direct change the text of current constitution but on the other hand they will have probably the bigger influence on the function of Polish constitutional and political system than several earlier direct amendment of constitution.

\section{CONCLUSIONS}

In summary, the economic and financial crisis that began in 2008 did not in itself lead to a new wave of constitutional legislation in Central Europe. ${ }^{47}$ The creation of a new constitutional identity in Hungary with the adoption of the Fundamental Law of 2011 has more to do with the local, specific political, social and perhaps partially legal historical conditions. ${ }^{48}$ At this time, the other Visegrad countries are characterised by maintenance of the constitutional status quo or only partial amendments, although it is true that in those countries, the turbulence caused by the crisis has not yet lead to a single party or coalition achieving the qualified majority required for constitutional reform. Among the Czech and Slovakian elites, the need for a new constitution has not arisen to date. Many people believe

45 The Polish Sejm adopted the new law on 7 July, and at the end of July it was also supported by 66 of the 100 senators of the Senate. The core provision of the new law is that in important cases, the 15-strong body may issue valid rulings in the presence of at least 11 of the judges. The previous law, adopted in December last year - which was found unconstitutional by the Polish Constitutional Court itself and criticized for paralysing the court by the European Commission and the opposition set the minimum number of judges required for a valid decision at 13 and required a two-thirds majority. According to the new legislation, full sessions of the body would make decisions about parliamentary bills vetoed by the President, statutes that concern the Constitutional Court, the scopes of authority of certain government bodies and the unconstitutional operation of individual political parties. The statute also prescribes that the president of the Constitutional Court is obliged to allow the judges appointed by the head of state to participate in the work of the body. That is because due to a resolution of the Constitutional Court, 3 of the 5 judges appointed in the autumn of 2015 by the head of state are still prevented from participating. Currently the judges elected by the new PiS majority of parliament are the active members of the Polish Constitutional Court.

46 Ewa Poplawska's essay in the present issue is about the debates around the Polish Constitutional Court. The details are available in that issue.

47 During the $20^{\text {th }}$ century, there have been three such significant waves. The first one took place after World War I, the second one at the end of the 1940s and the beginning of the 1950s (when the constitutions of the so-called people's democracies were written), while the third one occurred after the fall of Communism in 1989. The latter could also be called the wave of constitutions of the democratic transition, whose impact is still being felt in most countries.

48 Primarily the existence of the tradition of the historical constitution and even more so the fact that in Hungary, no new constitution was formally enacted after 1989. 
that in the hectic period of crises that we are living through, when many things are changing and not for the better, it would be perhaps more expedient not to meddle with the documents of public law that fundamentally reflect the optimistic, liberal and democratic spirit of the 1990s. Under such conditions, changing their content would probably not result in better and more democratic formulations.

The constitutional amendments adopted after 2008 were only partially a reaction to the great economic and financial crisis. Rather, many amendments were reflections on structural problems that had existed previously, e.g., the operational disturbances and internal debates in the Slovakian judicial system; the issues of immunity concerning the Czech legislature and constitutional judges); the problems arising in the course of day-to-day politics that had not been fully considered previously (such as the more exact regulation of the right of the Czech head of state to dissolve the houses of parliament) or they introduced long-debated and still timely changes (e.g. the direct election of the Czech head of state). The measures that were indeed reactions to the above-mentioned great crisis were perhaps the items of legislation and measures concerning public funds and budgetary discipline, as exemplified primarily by a new section of the new Hungarian Fundamental Law and a separate Slovakian constitutional act. ${ }^{49}$ The Czech government has also prepared a similar bill, but it has not yet been adopted. In Poland, the original text of the 1997 constitution had already devoted a section to the management of public funds, although with a somewhat different angle than the Hungarian and Slovakian regulations adopted after the crisis.

Among new trends the protective measures applicable to natural assets and waters were introduced in the interest of future generations. These were inserted in a very forceful manner into the Hungarian and Slovakian constitutional systems during the period after the crisis. The reinforcement of such an ecological identity could be interpreted as a positive development, particularly if it were really consistent and applied to nuclear energy as well, for instance. However, the public law documents of the region are also characterised by a certain conservative 'revolutionary' mood, particularly in the definition of marriage as a relationship between a man and a woman; some family law measures aimed at improving demographic conditions, and the passages of the Hungarian Fundamental Law concerning a society based on work. The increased emphasis on the relationship between rights and obligations (particularly in Hungary and Poland) also fit that conservative 'new wave'. The function of constitutional courts is also beginning to be re-evaluated in the region. The previously very strong Hungarian Constitutional Court began to lose its position as the paramount public law check and balance in 2010/2011, and similar trends are gaining momentum in Poland. There, however, the governing majority does not have a qualified majority (yet). In Slovakia, due to a few highly debated and inconsistent decisions, the Constitutional Court is in an increasingly complex situation in relation to the head of state. In the Czech Republic, while some experts criticize the Constitutional Court for its excessive activist role, the existing parliamentary balance of power implies that radical reform in that area is unlikely. It is certainly clear that although the constitutional systems of the Central European region, formed after 1989, began to shift slowly after 2008, in most countries they still retain the decisive majority of the features they acquired during the fall of Communism. For the time being, any new trend can only be said to exist as a potentiality but, of course, a great deal depends on how the situation develops in the EU and, particularly, in Poland.

49 Constitutional Act no. 493 of 2011 of the Republic of Slovakia on budgetary responsibility. 


\section{LITERATURE}

Blokker, Paul, New Democracies in Crisis? A Comparative Constitutional Study of the Czech Republic, Hungary, Poland, Slovakia and Romania (Routledge 2013).

Bucholc, Marta, 'The Polish Constitutional Crisis 2015-2016: A Figurational Perspective.' (2016) 2 Human Figurations <http://hdl.handle.net/2027/spo.11217607.0005.210> accessed 31 July 2017.

Chronowski, Nóra, 'Az Alaptörvény a többszintü európai alkotmányosság hálójában' (The Fundamental Law in the Network of the European Multi-Level Constitutionalism) in GárdosOrosz, Fruzsina and Szente, Zoltán (eds), Alkotmányozás és alkotmányjogi változások Európában és Magyarországon. (Nemzeti Közszolgálati és Tankönyvkiadó 2014) 109-30.

Chruściak, Ryszard and Osiatyński, Wiktor, Tworzenie konstytucji w Polsce w latach 1989-1997. (Creation of constitution in Poland between 1989 and 1997) (IPN 2001).

Cserny, Ákos, 'A kormányzati működés egyes összetevőinek változása az újkori alkotmányozás során' (The Change in Certain Elements of Governance in New Age Constitutionalism of the Governance in the Making of Modern Constitutions) in Gárdos-Orosz, Fruzsina and Szente, Zoltán (eds), Alkotmányozás és alkotmányjogi változások Európában és Magyarországon. (Nemzeti Közszolgálati és Tankönyvkiadó 2014) 292-95.

Cserny, Ákos, 'Hungarian Governmental Operation from a European View.' in Szente, Zoltán, Mandák, Fanni and Fejes, Zsuzsanna, Challenges and Pitfalls in the Recent Hungarian Constitutional Development. Discussing the New Fundamental Law of Hungary. (L'Harmattan 2015) 131-47.

Erdős, Csaba, 'Az 1989-es Alkotmányon nyugvó alkotmánybírósági határozatok hatályon kívül helyezésének egyes aspektusai' (Comments on the annulment of the former Constitutional Court decisions by the Fourth Amendment to the Fundamental Law) Gárdos-Orosz Fruzsina and Szente Zoltán (eds), Alkotmányozás és alkotmányjogi változások Európában és Magyarországon. (NKE KTK 2014) 397-417.

Fejes, Zsuzsanna, 'Constitutional Identity and Historical Constitution Clause in the Hungarian Fundamental Law and its Effects on the Constitutional Interpretation.' in Szente, Zoltán, Mandák, Fanni and Fejes, Zsuzsanna (eds), Challenges and Pitfalls in the Recent Hungarian Constitutional Development. Discussing the New Fundamental Law of Hungary (L'Harmattan 2015) 25-44.

Fekete, Balázs, 'The National Avowal: More than a Conventional Preamble to a Constitution' in Szente, Zoltán, Mandák, Fanni and Fejes, Zsuzsanna (eds), Challanges and Pitfalls in the Recent Hungarian Constitutional Development. Discussing the New Fundamental Law of Hungary (L'Harmattan 2015) 11-24.

Gárdos-Orosz, Fruzsina 'Judicial Review of Constitutional Amendments - the Hungarian Case in Context' in Szente, Zoltán and Mandák, Fanni and Fejes, Zsuzsanna (eds) Challenges and Pitfalls in the Recent Hungarian Constitutional Development. Discussing the New Fundamental Law of Hungary (L'Harmattan 2015) 114-28.

Jirásková, Věra, 'Zvláštnosti parlamentní formy vlády $\mathrm{v}$ České republice' (Specifies of the parlamentarian form of government in the Czech Republic) in Jirásek, Jiří and Witkowski, Zbigniew (eds), Proměny dělby moci. Dělba moci v ústavním systému České republiky a Polské republiky. (Olomouc 2015) 56.

Körösényi, András, 'A magyar demokrácia három szakasza és az Orbán-rezsim' (Three Stages of the Hungarian Democracy and the Orbán-Regime) in Körösényi, András (ed), A Magyar politikai rendszer - negyedszázad után. (Osiris - MTA TK 2015) 417-18.

Kudrna, Jan, 'Two Preambles in the Czech Constitutional System' (2011) 1 Acta Juridica Hungarica $19-22$.

Mandák, Fanni, 'Signs of Presidentialization in Hungarian Government Reforms - Changes After the New Fundamental Law' in Szente, Zoltán, Mandák, Fanni and Fejes, Zsuzsanna, Challenges and Pitfalls in the Recent Hungarian Constitutional Development. Discussing the New Fundamental Law of Hungary (L'Harmattan 2015) 148-68.

Schweitzer, Gábor, ‘Alaptörvény - sarkalatos törvény - történeti alkotmány’ (Fundamental Law Cardinal Law - Historical Constitution) in Boóc, Ádám and Fekete, Balázs (eds), Il me semblat que j'etais moi-méme ce dont parlait l'ouvrage - Liber Amicorum Endre Ferenczy (Patrocinium 2012) 258-65. 
Szalai, András, ‘A hatalommegosztás átalakulása 2010 után' (The Separation of Powers after 2010) in Gárdos-Orosz, Fruzsina and Szente, Zoltán (eds), Alkotmányozás és alkotmányjogi változások Európában és Magyarországon (NKE KTK, Budapest, 2014) 279-80.

Szente, Zoltán, 'The Decline of Constitutional Review in Hungary - Towards a Partisan Constitutional Court' in Szente, Zoltán, Mandák, Fanni and Fejes, Zsuzsanna (eds), Challenges and Pitfalls in the Recent Hungarian Constitutional Development. Discussing the New Fundamental Law of Hungary (L'Harmattan 2015) 185-210.

Téglási, András, 'Az Alkotmánybíróság alapjogvédelmi gyakorlata az Alaptörvény hatálybalépése után,' 'Fundamental rights protection by the Constitutional Court after the Fundamental Law has entered into force] in Gárdos-Orosz, Fruzsina and Szente, Zoltán (eds), Alkotmányozás és alkotmányjogi változások Európában és Magyarországon (NKE KTK 2014) 317-39.

Tomoszek, Maxim, 'Prezident republiky a vláda - vzájemné vztahy,' (President of republic and government - relationships) in Jirásek, Jiří and Witkowski, Zbigniew (eds), Promény dělby moci. Dèlba moci v ústavním systému České republiky a Polské republiky. (Olomouc 2015) 152-59.

Wilgocki, Michał and Kośmiński, Paweł 'PiS i Kukiz 15 składają projekt zmiany konstytucji. Chcą wygasić kadencje wszystkich sędziów Trybunału' (PiS and Kukiz'15 proposal the project of the changes of constitution.) 18.12.2015. Gazeta Wyborcza. <http://wyborcza.pl/1,75398,19367467, pis-i-kukiz-skladaja-projekt-zmiany-konstytucji-chca-wygasic.html?disableRedirects=true $>$ accessed 31 July 2017 